\title{
Potential Link between T102C Polymorphism in the Serotonin Receptors (5-HT2A) Gene and Treatment Response of Risperidone on Schizophrenia
}

\author{
Saidah Syamsuddin*(D), Andi Fatimah Yuniasari (D), Faisal Idrus, Sonny T. Lisal \\ Department of Psychiatry, Faculty of Medicine, Hasanuddin University, Makassar, Indonesia
}

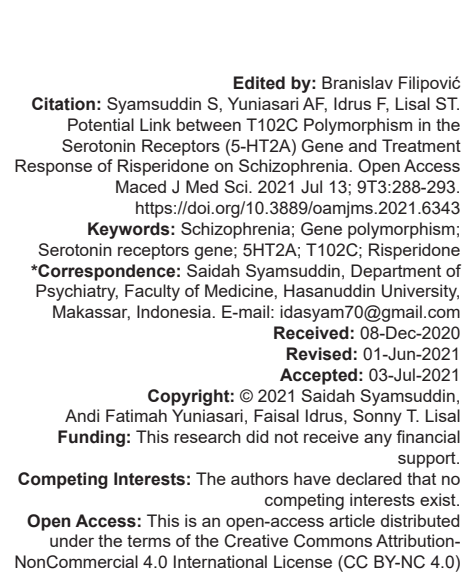

\section{Background}

Schizophrenia is a debilitating mental illness that affects $1 \%$ of the population, with an age of onset in the late $10 \mathrm{~s}$ or early $20 \mathrm{~s}$. The disorder usually follows a chronic relapsing-remitting course, and severely limits the individual's ability to work and integrate into society. The overall cost of caring for people with schizophrenia is being one of the most expensive disorders across the adult lifespan [1]. Subsequent clinical experience with antipsychotic drugs indicated that approximately one-third of patients failed to response to treatment. However, the possibility of relapse in patients with good response still exists.

Risperidone, the most commonly prescribed atypical antipsychotic in Indonesia, has been reported to be favorable for treating both positive and negative symptoms of schizophrenia. Risperidone has moderate to very high affinity for serotonin receptors (5-HT2A) and is also a potent inhibitor of dopamine-D2 receptors [2]. It has been hypothesized that clinical response to antipsychotic drugs may be determined by genetic variation in the neurotransmitter receptors to which the drug binds. In a way, alterations in genes coding for neuroleptics receptor proteins may affect their binding affinities for neuroleptics, the efficiency of signal transduction, or their level of expression, which, in turn, may alter the drug's therapeutic action [3].

The involvement of the serotonin (5-hydroxytryptamine; 5-HT) system in the etiology of schizophrenia has been hypothesized [4]. It has been shown that the number of 5-HT2A receptors is decreased in the brain prefrontal cortex of schizophrenia patients, as well as in relation to treatment with antipsychotic drugs [5]. Moreover, a positive association between different polymorphisms of the $5-\mathrm{HT} 2 \mathrm{~A}$ receptors gene and schizophrenia has been reported [6]. $5-\mathrm{HT} 2 \mathrm{~A}$ receptor is widely distributed in the brain, with 
highest concentrations in the cortex, and is localized on cortical and hippocampal pyramidal glutamatergic neurons, as well as on g-aminobutyric acid (GABA) ergic interneurons, both of which play a key role in schizophrenia [6], [7], [8], [9]. 5-HT2A receptors is also located in the substantia nigra and ventral tegmentum, from which the nigrostriatal and mesocorticolimbic dopamine neurons, respectively, arise, as well as their terminal regions, indicating the possibility of a relevant role for these receptors in modulating many of the actions of antipsychotic drugs [9].

Recent studies have found different results of potential link between T102C polymorphism in the $5 \mathrm{HT} 2 \mathrm{~A}$ receptors gene and treatment response in schizophrenia. Investigation in Chinese schizophrenia subjects with $\mathrm{C} / \mathrm{C}$ genotype predicted better response to risperidone than $\mathrm{T} / \mathrm{T}$ and $\mathrm{T} / \mathrm{C}$ genotype as well as in Korean people [10], [11]. One of the investigation in Turkey origin showed that the subjects who had homozygous for $\mathrm{T} / \mathrm{T}$ genotype was found to give better response to risperidone treatment than the patients who had $\mathrm{C} / \mathrm{C}$ and $\mathrm{T} / \mathrm{C}$ genotypes with respect to SANS and BPRS score [12]. In contrast, there was a study in Japanese people reported no association between T102C polymorphism in the 5-HT2A receptors and response therapy of risperidone [13].

With these distinctive findings obtained from studies in several populations, there is a need to determine the potential link between T102C polymorphism in the $5-\mathrm{HT} 2 \mathrm{~A}$ receptors gene and treatment response of schizophrenia patients in Indonesia who received risperidone. Since Indonesia has numbers of ethnic groups, therefore in the present study, we were focusing in the genotype of Makassar ethnic group.

\section{Methods}

This prospective cohort observational study involved 200 subjects. We divided the subjects into two groups. First group was a hundred schizophrenic inpatients in Prefecture Mental Hospital of South Sulawesi (Makassar, Indonesia). The patients would be included if: (1) They were diagnosed as schizophrenia according to DSM-V by psychiatrist who was in charge in the ward at that time, (2) no significant organic or neurologic disorders, (3) the patients were treated with risperidone in therapeutic dose from 2 to $4 \mathrm{mg}$ by psychiatric who was in charge in the ward at that time, and (4) they had no history of alcohol or drug abuse in the previous 12 months, (5) they were ranging from 18 to 40 years of age [14]. The second group was a hundred of healthy volunteers ranging from 18 to 40 years of age with no history of psychiatric disorder or family history as a comparison of 5-HT2A receptors gene polymorphism distribution. All subjects provided written informed consent.

Clinical improvement of schizophrenia group assessed 6 times in 4 weeks (when admitted to the hospital; transferred to sub-acute ward; the $1^{\text {st }}$; the $2^{\text {nd }}$; the $3^{\text {rd }}$; and the $4^{\text {th }}$ weeks) using Positive and Negative Symptom Scale (PANSS). Clinical Global Impression (CGI) scale were used to measure illness severity when admitted to the hospital (CGI-S); global improvement on the $4^{\text {th }}$ week (CGI-I); and therapeutic response on the $4^{\text {th }}$ week (CGI-E). This research study obtained approval from the Ethics Committee of Hasanuddin University.

\section{Molecular analysis}

Venous blood samples $(3 \mathrm{ml})$ were collected in ethylenediaminetetraacetic acid (EDTA) containing tubes. We conducted an allele specific polymerase chain reaction (PCR) based restriction fragment length polymorphism (PCR-RFLP) to genotype for serotonin receptors (5-HT2A). The primers 5-HT2AF5'-CTGTCTGCTACAAGTTCTGGCTTT'-3 and 5-Ht2A-R5'-CTGCAGCTTTTTCTCTAGGG-3 were used in this study. PCR tubes were inserted into the PCR machine and set up the machine by 35 cycles with a temperature of $95^{\circ}$ for $30 \mathrm{~s}, 60^{\circ}$ for $30 \mathrm{~s}$, and $72^{\circ}$ for $30 \mathrm{~s}$. The MSp1 enzyme was used to obtain a 5-HT2A receptor T102C gene polymorphism. Samples were incubated at $37^{\circ}$ for $15 \mathrm{~min}$. Then, an electrophoresis of $2 \%$ agarose was performed with ethidium bromide. Allele 1 (T102C allele) was represented by the uncut $342 \mathrm{bp}$ PCR product, and allele 2 (C102) allele consisted of two fragments 215 and $126 \mathrm{bp}$ (Figure 1).

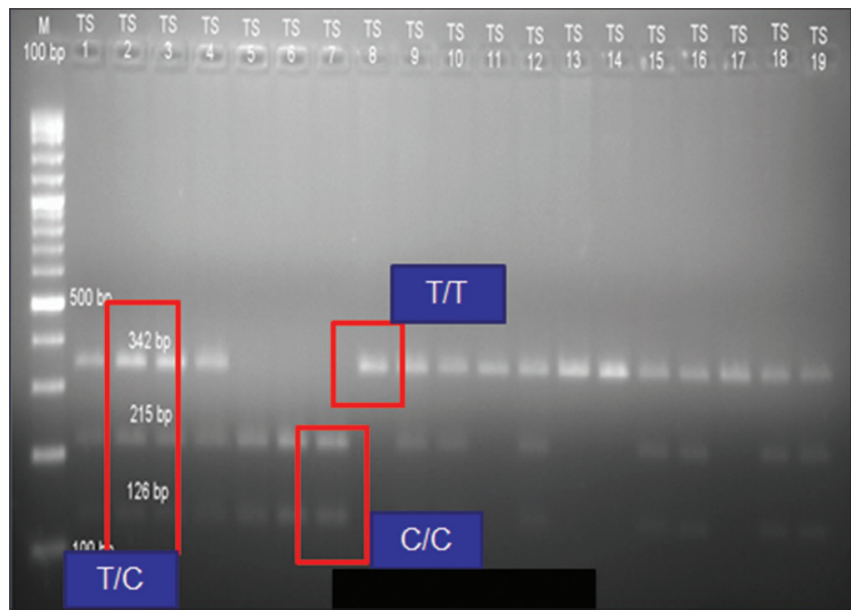

Figure 1: PCR-RFLP results of $T 102 C$ polymorphism in the $5-H T 2 A$ Receptors Gene in Schizophrenia Subjects. PCR Products of 5-HT2A and Msp1 restriction enzyme: 342 bp: T/T, 215 and $126 \mathrm{bp}$ C/C , 342,215 and 126 bp: T/C. Lane 1, 2, 4, 5, 8, 9, 14, 15, 16, 17 18: T/C Genotype, Lane 3, 6, 7, 10, 12, 13, 19: T/T Genotype, Lane 11: C/C Genotype 
Statistical analysis was performed using SPSS (Statistical Package for the Social Sciences) 22.0 program for windows. Chi-square and one-way ANOVA test were used for the statistical analysis of the data.

\section{Results}

Baseline characteristics on patients in the schizophrenia group and healthy volunteers group

Demographic characteristics of subjects were revealed and compared in Table 1. The schizophrenia group included a total of 100 (65 males and 35 females) and the healthy volunteers group included a total 100 (39 males and 61 females). The presentation of subjects with $\geq 30$ years old was significantly higher in Schizophrenia Group; nevertheless, subjects below 30 years old significantly higher in Healthy Volunteers Group. There was a significant difference in age and gender existed in the Schizophrenia Group and Healthy Volunteers Group with $p<0.001$ ( $p<0.005)$.

Table 1: The clinical baseline characteristics

\begin{tabular}{llll}
\hline Characteristics & $\begin{array}{l}\text { Schizophrenia } \\
\text { group }(\mathrm{n}=100)(\%)\end{array}$ & $\begin{array}{l}\text { Healthy volunteers } \\
\text { group }(\mathrm{n}=100)(\%)\end{array}$ & $\begin{array}{l}\mathrm{p} \text {-value } \\
(\mathrm{p}<0.05)\end{array}$ \\
\hline $\begin{array}{llll}\text { Age (years) } \\
<20 \text { years }\end{array}$ & $1(1)$ & $19(19)$ & $<0.001$ \\
$20-29$ years & $27(27)$ & $70(70)$ & \\
$30-39$ years & $39(39)$ & $11(11)$ & \\
$\geq 40$ & $33(33)$ & $0(0)$ & $<0.001$ \\
Gender & & $39(39)$ & \\
$\quad$ Male & $65(65)$ & $61(61)$ & \\
Female & $35(35)$ & Minimal Improvement: $+25 \%$ reduction of the total scales compared with baseline on the PANSS scores.
\end{tabular}

Much Improvem. OR: Odds Ratio ; Cl: Confidence Interval
Genotype distribution of 5-HT2A receptors in the schizophrenia group and healthy volunteers group

We found no significant difference in genotype distribution between schizophrenic group (n TT $=36$, $\mathrm{TC}=58, \mathrm{CC}=6$ ) and healthy volunteers group ( $\mathrm{n}$ TT $=44$, $\mathrm{TC}=50, \mathrm{CC}=6)$ with $p=0,498(\mathrm{p}<0.05)$ (Figure 2).

\section{Association of PANSS score with T102C} polymorphism in the 5-HT2A receptors gene

There was no significant difference improvement rates in PANSS 1 to PANSS 5 between $\mathrm{T} / \mathrm{T}, \mathrm{T}, \mathrm{C}$ and $\mathrm{C} / \mathrm{C}$ genotype with $\mathrm{p}<0.001(\mathrm{p}>0.05)$ (Figure 3). PANSS 6 displayed a significant improvement rates $(p<0.05)$ in $T / T$ genotype compared to $T / C$ and $\mathrm{C} / \mathrm{C}$ genotype.

T102C polymorphism in the 5-HT2A receptors displayed a significant association with PANSS total improvement rates (Table 2). Our findings showed that the subjects who had homozygous for T/T genotypes were found to give much improvement to risperidone than the subjects who were $\mathrm{C} / \mathrm{C}$ and $\mathrm{T} / \mathrm{C}$ genotypes with $p<0.001(p<0.05)$. In addition, subjects with T/C and $\mathrm{C} / \mathrm{C}$ genotype appeared to confer higher possibility

Table 2: Association of PANSS score with T102C polymorphism in the 5-HT2A receptors gene

\begin{tabular}{llllll}
\hline Genotype & \multicolumn{2}{l}{ Treatment response } & Total & p-value & OR $(95 \% \mathrm{Cl})^{*}$ \\
\cline { 2 - 3 } & Minimal improvement & Much improvement & & \\
\hline T/T & 3 & 33 & 36 & $<0.001$ & 1.0 \\
& $8.3 \%$ & $91.7 \%$ & $100 \%$ & \\
T/C & 35 & 23 & 58 & 16.7 \\
& $60.3 \%$ & $39.7 \%$ & $100 \%$ & $(4.6-61.0)$ \\
$\mathrm{C} / \mathrm{C}$ & 3 & 3 & 6 & $11,0(1.5-80.4)$ \\
& $50 \%$ & $50 \%$ & $100 \%$ & \\
Total & 41 & 59 & 100 & \\
& $41 \%$ & $59 \%$ & $100 \%$ & \\
\hline
\end{tabular}

\section{Schizophrenia Group}

\section{Healthy Volunteers Group}

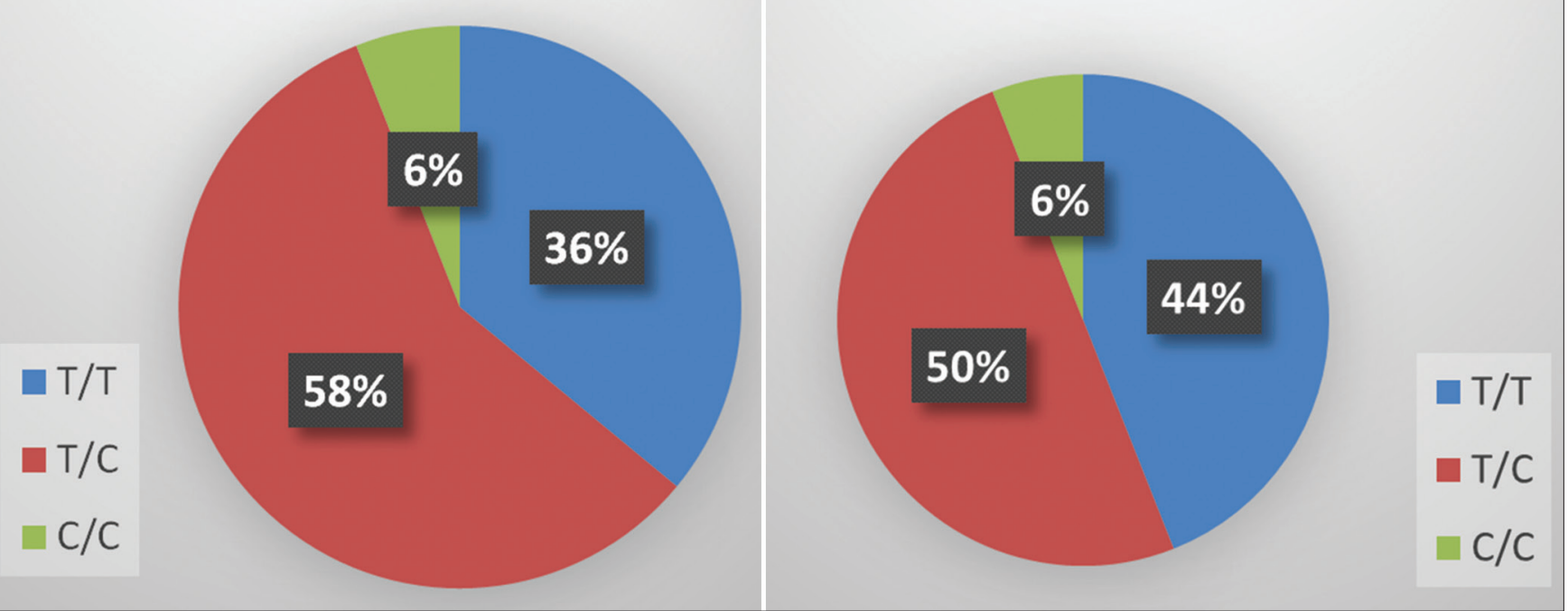

Figure 2: T102C Polymorphism in the 5-HT2A Receptors Genotype Distribution In Schizophrenia Group and Healthy Volunteers Group. No significant difference in genotype distribution between schizophrenic group $(n T T=36, T C=58, C C=6)$ and healthy volunteers group ( $n T T=44, T C=50, C C=6$ ) 


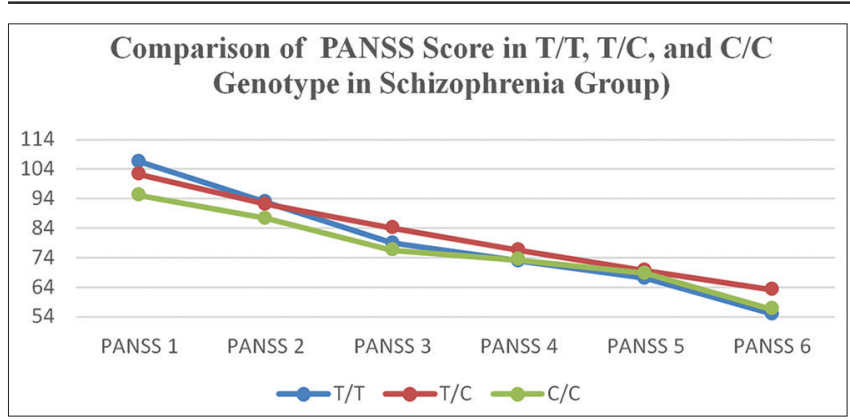

Figure 3: Comparison of Risperidone Response Therapy Evaluated by PANSS Score in 4 Weeks in Schizophrenia Group. PANSS 1: Evaluated when admitted to the hospital; PANSS 2: Evaluated when transferred to sub-acute ward; PANSS 3: Evaluated after 1 week given risperidone; PANSS 4: evaluated after 2 weeks given risperidone; PANSS 5: Evaluated after 3 weeks given risperidone; PANSS 6: evaluated after 4 weeks given risperidone. No significant difference improvement rates in PANSS 1 to PANSS 5 between T/T, $T$, $C$, and $C / C$ genotype. PANSS 6 displayed a significant improvement rates $(p<0.05)$ in $T / T$ genotype compared to $T / C$ and $C / C$ genotype.

than subjects with $\mathrm{T} / \mathrm{T}$ genotype to sustain minimal improvement in risperidone treatment response 16.7 times and 11 times, respectively.

\section{Association of CGI score with T102C polymorphism in the 5-HT2A receptors}

Similarly for CGI-I (Table 3) and CGI-E scale (Table 4), the subjects with T/T genotype showed a better respond to risperidone treatment $(p<0.05)$ compared to subjects with $\mathrm{T} / \mathrm{C}$ and $\mathrm{C} / \mathrm{C}$ genotype. For the assessment of side effects on the CGI-E scale, only four subjects (4\%) experienced extra pyramidal syndrome (EPS) side effects that significantly interferes with patient's function therefore trihexyphenidyl $2 \mathrm{mg}$ was added, 1 tablet per $12 \mathrm{~h}$. The CGI-S was unable to be linked with the polymorphism because the results of the assessment were all considerable "severely ill."

\section{Discussion}

There were two major findings in the presence study. First, there was no significant difference in T102C polymorphism in the 5-HT2A receptors gene distribution between Schizophrenia group and Healthy Volunteers Group. Second, there was a potential link between T102C polymorphism in the 5-HT2A receptors gene and risperidone treatment response on schizophrenia subjects.

Our data showed same distribution of T102C polymorphism in the 5-HT2A receptors gene in Schizophrenia Group and Healthy Volunteers Group. T/C genotype is mainly found amongst the subjects with a prevalence of $58 \%$ in Schizophrenia Group and $50 \%$ in the Healthy Volunteers Group. T/T genotype
Table 3: Association of CGI-I score with T102C polymorphism in the 5-HT2A receptors gene

\begin{tabular}{|c|c|c|c|c|}
\hline \multirow[t]{2}{*}{ Genotype } & \multicolumn{2}{|l|}{ CGI-I } & \multirow[t]{2}{*}{ Total } & \multirow[t]{2}{*}{$\mathrm{p}$-value } \\
\hline & Much improved & Very much improved & & \\
\hline \multirow[t]{2}{*}{$\mathrm{T} / \mathrm{T}$} & 3 & 33 & 36 & \multirow[t]{8}{*}{$<0.001$} \\
\hline & $8.3 \%$ & $91.7 \%$ & $100 \%$ & \\
\hline \multirow[t]{2}{*}{$T / C$} & 35 & 23 & 58 & \\
\hline & $60.3 \%$ & $39.7 \%$ & $100 \%$ & \\
\hline \multirow[t]{2}{*}{$\mathrm{C} / \mathrm{C}$} & 3 & 3 & 6 & \\
\hline & $50 \%$ & $50 \%$ & $100 \%$ & \\
\hline \multirow[t]{2}{*}{ Total } & 41 & 59 & 100 & \\
\hline & $41 \%$ & $59 \%$ & $100 \%$ & \\
\hline
\end{tabular}

was found in $36 \%$ subjects in Schizophrenia Group and in $44 \%$ subjects in Healthy Volunteers Group. For $\mathrm{C} / \mathrm{C}$ genotype, the prevalence was similar $6 \%$ of subjects in both groups. Based on these findings, we suspected T/C genotype may become dominant genotype of T102C polymorphism in the 5-HT2A receptors gene in our population. Despite of that, we assumed T102C polymorphism in the serotonin receptors gene unable to be a predictor for schizophrenia susceptibility in this population.

The results suggested a potential link of T102C polymorphism in the 5-HT2A receptors gene on risperidone treatment response evaluated in PANSS and CGI scale. In this study, subjects with T/T genotype showed better improvement in treatment compared to subjects with $\mathrm{T} / \mathrm{C}$ and $\mathrm{C} / \mathrm{C}$ genotype, suggested that $\mathrm{T} 102 \mathrm{C}$ polymorphism in the $5-\mathrm{HT} 2 \mathrm{~A}$ receptors gene played an important role in therapeutic response to risperidone. There needs to be an explanation of biological why $\mathrm{T} 102 \mathrm{C}$ polymorphism in the 5-HT2A receptor gene gave different responses in the treatment of schizophrenia, but there was possibility that binding affinity of $\mathrm{T} / \mathrm{T}$ genotype in $5-\mathrm{HT} 2 \mathrm{~A}$ receptor T102C was higher than the other genotypes such as

Table 4: Association of CGI-E score with T102C polymorphism in the 5-HT2A receptors gene

\begin{tabular}{lllll}
\hline Genotype & CGI-E & & Total & p-value \\
\cline { 2 - 3 } & Marked improvement & Moderate improvement & & \\
\hline T/T & 32 & 4 & 36 & $<0.001$ \\
& $88.9 \%$ & $11.1 \%$ & $100 \%$ & \\
T/C & 23 & 35 & 58 & \\
& $39.7 \%$ & $60.3 \%$ & $100 \%$ & \\
$\mathrm{C} / \mathrm{C}$ & 3 & 3 & 6 & \\
& $50 \%$ & $50 \%$ & $100 \%$ & \\
Total & 58 & 42 & 100 & \\
& $58 \%$ & $42 \%$ & $100 \%$ & \\
\cline { 1 - 2 } & Marked improvement: Vast improvement. Complete or nearly complete remission of all symptoms; &
\end{tabular}

$\mathrm{C} / \mathrm{C}$ and $\mathrm{T} / \mathrm{C}$ in serotonergic system [15]. Furthermore, a functional promoter's variant of 5-HT2A receptor might differentially alter transcription, thereby affecting the number of receptors. These results in line with Herken et al. investigated in Turkey origin showed that there was an association between T102C polymorphism in the 5-HT2A receptors gene and risperidone response therapy in Schizophrenia showed that subjects with homozygous T/T genotype were found to give better response to risperidone treatment than subjects with $\mathrm{C}$ allele $\mathrm{C} / \mathrm{C}$ and $\mathrm{T} / \mathrm{C}$ genotype. Therefore, we assumed that T102C polymorphism in the $5-\mathrm{HT} 2 \mathrm{~A}$ receptors gene could be used to predict treatment response of risperidone or 
other antipsychotic which has moderate to very high affinity for the serotonergic receptors [12].

Recent studies have found different results of potential link between T102C polymorphism in the $5 \mathrm{HT} 2 \mathrm{~A}$ receptors gene and treatment response in schizophrenia. Investigation in Chinese schizophrenia subjects with $\mathrm{C} / \mathrm{C}$ genotype predicted better response to risperidone than $\mathrm{T} / \mathrm{T}$ and $\mathrm{T} / \mathrm{C}$ genotype as well as in Korean people. Ethnic diversity may be one of the factors that affected the outcome of this study [10], [11].

According to our findings, subjects with $\mathrm{T} / \mathrm{T}$ genotype will give better response if treated by antipsychotic with moderate to very high affinity for the serotonergic receptors. Whereas subjects with $\mathrm{T} / \mathrm{C}$ and $\mathrm{C} / \mathrm{C}$ genotype will give better response, if treated by antipsychotic with low-to-moderate affinity for the serotonergic receptors or higher affinity to other receptor.

The correlation between age and gender with treatment response was not examined. This might be a limitation of present study. Although gender is a predictor of clinical response to antipsychotic treatment, its influence it not the same for all antipsychotic. There was another study found that risperidone had no difference in gender for clinical response [16]. In the present study, to elude the confounding factors of treatment response, we excluded younger $(<18$ years of age) and elder ( $\geq 40$ years of age) population.

\section{Conclusion}

There were polymorphisms of the 5-HT2A Receptor (T102C) gene in people with schizophrenia and healthy volunteers $(\mathrm{T} / \mathrm{T}, \mathrm{T} / \mathrm{C}$ and $\mathrm{C} / \mathrm{C})$. Our result supported that there was a potential link between T102C polymorphism in the 5 HT2A receptors gene and treatment response of risperidone. $\mathrm{T} / \mathrm{T}$ genotype was found to give better improvement than $\mathrm{C} / \mathrm{C}$ and $\mathrm{T} / \mathrm{C}$ genotypes. Our findings suggested that genetic screening needs to be performed to optimize therapeutic strategies of schizophrenia patients. Further studies are needed to find the possible impacts of genes interaction in the occurrence and response therapy of schizophrenia patients.

\section{Declarations}

\section{Authors' contributions}

All the authors were involved in the conception of this study SS, FI, AFY, and STL to interpretation of the research findings and contributed to the drafting of the manuscript. All authors read and approved the final manuscript.

\section{Acknowledgments}

The authors would like to acknowledge and thank to the participants who volunteered and took part in this study. We also would like to acknowledge the important support and contribution of Arifin Seweng, M.D.

\section{Ethics approval and consent to participate}

The research has been permitted and acknowledged by Hasanuddin University Ethic Medical Committee. Before each interview, each participant was given written information on the study. Each participant was also informed that his or her participant was voluntary. Before each interview, we emphasized the importance of maintaining confidentiality in relation to patient cases. All participants provided written consent to participate in this study.

\section{Availability of data and materials}

The datasets used and analyzed for this study are available from the corresponding author on reasonable request.

\section{References}

1. Bartels SJ, Clark RE, Peacock WJ, Dums AR, Pratt SI. Medicare and medicaid costs for schizophrenia patients by age cohort compared with costs for depression, dementia, and medically ill patients. Am J Geriatr Psychiatry. 2003;11(6):648-57. https:// doi.org/10.1097/00019442-200311000-00009 PMid: 14609805

2. Stahl SM. Stahl's Essential Psychopharmacology. $4^{\text {th }}$ ed. New York: Cambridge University Press; 2013. p. 129-236.

3. Arranz MJ, Munro J, Owen MJ, Spurlock G, Sham PC, Zhao J, et al. Evidence for association between polymorphisms in the promoter and coding regions of the 5-HT2A receptor gene and response to clozapine. Mol Psychiatry. 1998;3(1):61-6. https:// doi.org/10.1038/sj.mp.4000348

PMid:9491814

4. Meltzer HY. The role of serotonin in schizophrenia and the place of serotonin-dopamine antagonist antipsychotics. J Clin Psychopharmacol. 1995;15 Suppl 1:2S-3S. https://doi. org/10.1097/00004714-199502001-00001

PMid:7730497

5. Dean $B$. The cortical serotonin $2 \mathrm{~A}$ receptor and the pathology of schizophrenia: A likely accomplice. J Neurochem. 2003;85(1):1-13.

PMid:12641722 
6. Li D, Duan Y, He L. Association study of serotonin 2A receptor (5-HT2A) gene with schizophrenia and suicidal behavior using systematic meta-analysis. Biochem Biophys Res Commun. 2006;340(3):1006-15. https://doi.org/10.1016/j. bbrc.2005.12.101

7. Hoyer D, Pazos A, Probst A, Palacios JM. Serotonin receptors in the human brain. II. Characterization and autoradiographic localization of 5-HT1C and 5-HT2 recognition sites. Brain Res. 1986;376(1):97-107. https://doi. org/10.1016/0006-8993(86)90903-0

PMid:2941113

8. Jakab RL, Goldman-Rakic PS. 5-Hydroxytryptamine2A serotonin receptors in the primate cerebral cortex: Possible site of action of hallucinogenic and antipsychotic drugs in pyramidal cell apical dendrites. Proc Natl Acad Sci USA. 1998;95(2):735-40. https://doi.org/10.1073/pnas.95.2.735

PMid:9435262

9. Willins DL, Deutch AY, Roth BL. Serotonin5-HT2A receptors are expressed on pyramidal cells and interneurons in the rat cortex. Synapse. 1997;27(1):79-82. https://doi.org/10.1002/ (sici)1098-2396(199709)27:1<79::aid-syn8>3.0.co;2-a PMid:9268067

10. Kim B, Choi EY, Kim CY, Song K, Joo YH. Could HTR2AT102C and DRD3 Ser9Gly predict clinical improvement in patients with acutely exacerbated schizophrenia? Results from treatment responses to risperidone in a naturalistic setting. Hum Psychopharmacol. 2008;23(1):61-7. https://doi.org/10.1002/hup.897 PMid: 17924589

11. Lane HY, Chang YC, Chiu CC, Chen ML, Hsieh MH, Chang $\mathrm{WH}$. Association of risperidone treatment response with a polymorphism in the $5-\mathrm{HT}(2 \mathrm{~A})$ receptor gene. Am J
Psychiatry. 2002;159(9):1593-5. https://doi.org/10.1176/appi. ajp.159.9.1593

PMid:12202283

12. Herken H, Emin E, Koray E, Osman S, Sukru A. The relationship between the response to risperidone treatment and 5-HT2A receptor gene (T102C and 1438G/A) polymorphism in schizophrenia. Bull Psychpharmacol. 2003;13:161-6.

13. Yamanouchi $\mathrm{Y}$, Iwata N, Suzuki T. Effect of DRD2, 5-HT2A and COMT genes on antipsychotic response to risperidone. Pharmacogenomics J. 2003;3(6):356-61. https://doi. org/10.1038/sj.tpj.6500211

PMid: 14610521

14. Manual of Mental Disorder Fifth Edition (DSM-5). USA, American Psychiatrist Association; 2013.

15. Aneja J. Risperidone response in schizophrenia: A narrative review of pharmaco-genetic research. J Ment Health Clin Psychol. 2018;2:39-47. https://doi.org/10.29245/2578-2959/2018/4.1161

16. Usall J, Suarez D, Haro JM, SOHO Study Group. Gender differences in response to antipsychotic treatment in outpatients with schizophrenia. Psychiatry Res. 2007;153(3):225-31. https://doi.org/10.1016/j.psychres.2006.09.016

PMid:17681611

17. Leucht S, Engel R. What does the PANSS mean? Schizophr Res 2005;79(2-3):231-8. PMid:15982856

18. Haro JM, Kamath SA, Ochoa S, Novick D, Rele K, Fargas A, et al. The clinical global impression-schizophrenia scale: A simple instrument to measure the diversity of symptoms present in schizophrenia. Acta Psychiatr Scand Suppl. 2003;416:16-23. https://doi.org/10.1034/j.1600-0447.107.s416.5.x

PMid:12755850 